\title{
PENGEMBANGAN MEDIA PEMBELAJARAN INTERAKTIF MATA PELAJARAN PRAKARYA UNTUK SISWA SMP KELAS VIII
}

\author{
N. Simbolon ${ }^{1}$, I.K. Suartama ${ }^{2}$, L.P.P. Mahadewi ${ }^{3}$ \\ ${ }^{123}$ Program Studi Teknologi Pendidikan \\ Universitas Pendidikan Ganesha \\ Singaraja, Indonesia

\begin{abstract}
e-mail: natalinasimbolon12@undiksha.ac.id ${ }^{1}$, ik-suartama@undiksha.ac.id ${ }^{2}$, Lpp-mahadewi@undiksha.ac.id ${ }^{3}$
\end{abstract}

\begin{abstract}
Abstrak
Masalah dalam penelitian ini adalah rendahnya hasil belajar siswa pada mata pelajaran prakarya dan belum tersedia media interaktif untuk mendukung pembelajaran pada mata pelajaran prakarya tersebut. Oleh karena itu, penelitian ini bertujuan untuk mengembangkan media interaktif dan mengetahui validitas media interaktif dalam pembelajaran prakarya. penelitian pengembangan ini menggunakan model ADDIE (Analysis, Design, Development, Implementation, Evaluation). Hasil validitas produk dikatakan valid dengan masing-masing penilaian, a) hasil review ahli isi pembelajaran dengan persentase $97,5 \%$ dengan kategori sangat baik, b) hasil review ahli desain pembelajaran dengan persentase $88,57 \%$ dengan kategori baik, c) hasil review ahli media pembelajaran dengan persentase $84,44 \%$ dengan kategori baik, d) hasil review uji coba perorangan dengan persentase 93,33\% dengan kategori sangat baik, e) hasil review uji coba kelompok kecil dengan pesentase $94,58 \%$ dengan kategori sangat baik. Berdasarkan hal tersebut, media interaktif pembelajaran prakarya ini layak digunakan sebagai sumber belajar.
\end{abstract}

Kata kunci: ADDIE; Media Interaktif; Prakarya

\begin{abstract}
The problem in this research is by the low of the students' learning outcomes in Craft subject and the unavailable interactive media in supporting that vocational learning. Therefore, this research aimed to develop the interactive media and to know the validity of the interactive media in Craft learning. This development research used ADDIE (Analysis, Design, Development, Implementation, Evaluation) research model. Validity result of the product was Valid with each assessment, a) the results of the review of learning content experts with a percentage of $97.5 \%$ with a very good category, $b$ ) the results of the review of learning design expert with a percentage $88.57 \%$ with a good category, c) the results of the review of learning media expert with a percentage $84.44 \%$ with a good category, d) the results of the review of individual trial with $93.33 \%$ with a very good category,e) the results of the review of small group trial with a percentage $94.58 \%$ with a very good category. Based on the results, this Craft learning interactive media is worth it to use as a learning source.
\end{abstract}

Keywords : ADDIE; Interactive Media; Craft

\section{PENDAHULUAN}

Peningkatan mutu pendidikan menjadi perhatian penting dalam meningkatkan kualitas sumber daya manusia (Gil-Flores et al., 2017; Rokhman et al., 2014). Hal ini dikarenakan pendidikan merupakan suatu proses dimana seseorang memperoleh pengetahuan yang nantinya dapat membantu meningkatkan sumber daya manusia (Hendawi \& Nosair, 2020; Oke \& Fernandes, 2020). Dalam Undang-Undang Republik Indonesia Nomor 20 tahun 2003 
tentang Sistem Pendidikan Nasional, pasal 3 menyebutkan bahwa: "Pendidikan nasional bertujuan untuk berkembangnya potensi peserta didik untuk menjadi manusia yang beriman dan bertaqwa kepada Tuhan Yang Maha Esa, berakhlak mulia, sehat, berilmu, cakap, kreatif, mandiri dan menjadi warga negara yang demokkratis dan bertanggung jawab". Dalam proses pembelajaran khusunya dalam pembelajaran daring saat ini, tentu sangat membutuhkan media pembelajaran untuk mendukung proses pembelajaran agar berjalan sesuai dengan tujuan yang diharapkan (Buchori et al., 2017; Hanif, 2020). Kehadiran media pembelajaran tentu mampu meningkatkan mutu pembelajaran. Media pembelajaran adalah segala sesuatu yang dapat digunakan untuk menyalurkan pesan, sehingga dapat merangsang minat, pikiran dan perasaan belajar peserta didik (Boyd, 2019; Prasasti et al., 2019). Dalam hal ini, ada banyak media yang bisa digunakan dalam proses pembelajaran, seperti video, slide presentasi ataupun menggunakan media secara langsung (Bajrami \& Ismaili, 2016; Teng, 2019). Namun tidak menutup kemungkinan masih banyak guru-guru yang kurang dalam penggunaan Information Technology (IT) sehingga dalam pembelajaran daring maupun pembelajaran dikelas guru-guru lebih dominan memberikan pembelajaran kepada siswa hannya dengan menggunakan modul/e-modul dan ringkasan materi lainnya yang hannya berbentuk teks.

Berdasarkan hasil wawancara dan analisis kebutuhan melalui google form yang dilakukan dengan guru mata pelajaran prakarya kelas VIII SMP Laboratorium Undiksha Singaraja, maka diperoleh informasi bahwa sumber belajar yang digunakan guru dalam proses pembelajaran masih berupa media pembelajaran sederhana, seperti bahan ajar cetak dan media presentasi sederhana. hal ini dikarenakan kesibukan guru yang harus mempersiapakan bahan ajar untuk setiap kelas yang akan digunakan dalam setiap pembelajaran, sehingga menyebabkan siswa cenderung bosan dalam mengikuti pembelajaran ditambah lagi materi yang terdapat dalam bahan ajar cetak sangat padat dan membuat siswa kurang tertarik dalam belajar. Jika pendidik tidak inovatif dalam memfasilitasi proses pembelajaran maka akan berpengaruh pada hasil belajar siswa (Kamelia, 2019; Nonthamand, 2020). Sudjana (Nurrita, 2018:175) hasil belajar merupakan suatu kompetensi atau kecakapan yang dapat dicapai oleh siswa setelah melalui kegiatan pembelajaran yang dirancang dan dilaksanakan oleh guru disuatu sekolah atau kelas tertentu. Nilai rata-rata hasil UTS dan UAS siswa kelas VIII pada mata pelajaran Prakarya tahun ajaran 2020/2021 yaitu 70 , akan tetapi masih terdapat 7 siswa dari 29 siswa yang mendapat nilai dibawah KKM dan siswa yang hannya mencapai KKM. Berdasarkan latar belakang tersebut maka solusi yang dapat ditawarkan untuk dapat menarik perhatian siswa dalam belajar sehingga mampu meningkatkan hasil belajar siswa adalah dengan mengembangkan media pembelajaran interaktif.

Media interaktif adalah hasil perpaduan antara berbagai media yang berupa teks, gambar, grafik, sound, animasi, dan video yang digunakan untuk menyampaikan pesan kepada publik (Indah Septiani et al., 2020; Rahmi et al., 2019). Heinich (Annisa et al., 2018) juga bahwa mengemukakan media interaktif merupakan kumpulan materi pembelajaran yang menyertakan lebih dari satu jenis media yang disusun dalam satu topik yang didalamnya terdapat film strip, slide, videotape, rekaman, gambar, OHP, film pendek, peta, lembar kerja, grafik, bagan, brosur, objek nyata dan model. Desma, (2020:3) secara umum manfaat yang dapat diperoleh dalam penggunaan media pembelajaran interaktif yaitu; 1) lebih menarik, 2) lebih interaktif, 3) jumlah waktu mengajar dapat dikurangi atau lebih singkat, 4) kualitas belajar siswa dapat ditingkatkan 
dan proses belajar mengajar dapat dilakukan di mana dan kapan saja, serta sikap belajar siswa dapat ditingkatkan. Kelebihan media pembelajaran interaktif adalah, 1) Media pembelajaran dibuat dengan tujuan agar siswa lebih interaktif baik ketika pembelajaran didalam kelas maupun ketika siswa belajar secara mandiri, 2) Memberikan iklim afeksi secara individual, 3) Meningkatkan motivasi belajar siswa, 4) Media pembelajaran interaktif didesain untuk program pembelajaran mandiri, artinya kontrol pemanfaatannya sepenuhnya berada di tangan pengguna (Gonźalez et al., 2013; Majid et al., 2012).

Penelitian

pengembangan

didasarkan pada penelitian yang telah dilakukan sebelumnya sebelumnya oleh (Mustika et al., 2017) dalam penelitiannya tentang pengembangan media pembelajaran interaktif dengan menggunakan metode multimedia development life cycle. Rezeki \& Ishafit (2017) dalam penelitian pengembangan media pembelajaran interaktif untuk sekolah menengah atas kelas XI pada pokok bahasan momentum. Rahmi et al., (2019) pada penelitian pengembangan media pembelajaran interaktif macroflash 8 pada mata pelajaran tematik tema pengalamanku. Hasil penelitian yang telah dilakukan tersebut memperoleh hasil yang efektif dan menunjukkan bahwa media pembelajaran interaktif layak digunakan sebagai media pembelajaran untuk mendukung proses pembelajaran.

Berdasarkan pemaparan diatas, maka dapat dirumuskan tujuan dilaksanakannya penelitian pengembangan ini yaitu untuk mendeskripsikan proses pengembangan dan validitas media pembelajaran interaktif pada siswa kelas VIII SMP Laboratorium Undiksha Singaraja. Dengan media pembelajaran interaktif ini akan menjadi alternatif yang dapat dimanfaatkan oleh guru dalam mengembangkan dan menginovasikan pembelajaran yang lebih kreatif dan inovatif sehingga dapat mengingkatkan hasil belajar siswa.

\section{METODE}

Jenis penelitian ini adalah penelitian pengembangan (Research and Development/ R\&D). Penelitian dan pengembangan (Research and Development/ $R \& D$ ) merupakan metode penelitian mengembangkan dan menghasilkan suatu produk berupa materi, media, alat dan atau strategi pembelajaran, digunakan untuk mengatasi pembelajaran di kelas/laboratorium, dan bukan untuk menguji teori". Tegeh \& Kirna (2010:19). Model pengembangan yang digunakan dalam penelitian pengembangan ini adalah model ADDIE. Model ADDIE terdiri dari lima tahapan yaitu: 1) Analisis (analyze), 2) Desain (design), 3) Pengembangan (development), 4) Implementasi (implementation), 5) Evaluasi (evaluation).

Tahap pertama analisis (analyze) meliputi kegiatan sebagai berikut: (1) melakukan analisis kebutuhan, (2) analisis kompetensi, (3) melakukan analisis kompetensi karakteristik peserta didik tentang kapasitas belajar, pengetahuan, dan keterampilan yang dimiliki siswa, (4) analisis fasilitas yang ada disekolah. Tahap kedua yaitu perancangan (design) dilakukan dengan kerangka acuan sebagaian berikut: (1) sasaran media yang dirancang, (2) memilih dan menetapkan perangkat lunak/software yang akan digunakan, (3) merancang flowchart dan stroryboard, (4) merancang RPP, (5) menyusun instrumen penilaian. Tahap ketiga yaitu Pengembangan (development) yang meliputi kegiatan mengembangkan konten/isi media pembelajaran interaktif dan mengembangkan wujud media interaktif dari wujud desain menjadi produk nyata yang siap digunakan. Tahap keempat yaitu Implementasi (implement) hasil pengembangan diterapkan dalam pembelajaran untuk mengetahui pengaruhnya terhadap kualitas pembelajaran yang meliputi keefektifan, kemenarikan dan keefesienan media. Tahap 
terakhir yaitu tahap evalusi (evaluation), namun pada tahap ini peneliti tidak dapat melakukan tahap evaluasi atau uji efektivitas karena situasi pandemi covid-19, sehingga ini menjadi kekurangan dalam penelitian ini. Akan tetapi tidak menutup keungkinan peneletian ini nantinya dapat diselesaikan atau disempurnakan oleh peneliti lain.

Penelitian ini dilakukan di SMP Laboratorium Undiksha Singaraja yang terletak di Singaraja, kecamatan Buleleng, Kabupaten Buleleng, Provinsi Bali. Subjek dalam penelitian ini yaitu 1) ahli isi pembelajaran, 2) ahli desain pembelajaran, 3) ahli media pembelajaran, 4) siswa kelas VIII di SMP Laboratorium Undiksha Singaraja. Ahli isi pembelajaran merupakan seorang guru mata pelajaran prakarya yang mengajar di SMP Laboratorium Undiksha Singaraja. Ahli desain pembelajaran adalah seorang dosen yang mengajar di Program Studi Teknologi Pendidikan Universitas Pendidikan Ganesha. Ahli media pembelajaran adalah seorang dosen yang mengajar di Program Studi Teknologi
Pendidikan Universitas Pendidikan Ganesha. Subjek uji coba produk adalah 3 orang siswa kelas VIII SMP Laboratorium Undiksha Singaraja untuk uji coba perorangan dengan prestasi belajar siswa tinggi, sedang dan rendah. Uji coba kelompok kecil melibatkan 6 orang siswa kelas VIII SMP Laboratorium Undiksha Singaraja yang terdiri dari 2 orang siswa dengan prestasi belajar tinggi, 2 orang siswa dengan prestasi belajar sedang dan 2 orang siswa dengan prestasi belajar rendah.

Metode pengumpulan data yang digunakan dalam penelitian ini menggunakan kusioner. Metode kuesioner merupakan cara memperoleh atau mengumpulkan data dengan mengirimkan suatu daftar pertanyaan atau pernyataanpernyataan kepada responden/subjek untuk dijawab secara tertulis (Agung, 2017). Instrumen dipergunakan untuk memperoleh data hasil dari review para ahli dan uji coba perorangan, dan kelompok kecil. Adapun kisi-kisi instrumen yang digunakan dalam penelitian yaitu tersaji pada tabel 1, 2, 3 dan 4.

Tabel 1. Kisi-Kisi Instrumen Ahli Isi Pembelajaran

\begin{tabular}{|c|c|c|}
\hline No & Aspek & Komponen \\
\hline \multirow[t]{4}{*}{1.} & Aspek & Kesesuaian materi dengan kompetensi dasar \\
\hline & Pembelajaran & Kesesuaian materi dengan tujuan pembelajaran \\
\hline & & Keluasan isi/uraian materi \\
\hline & & Kejelasan Penyajian materi \\
\hline \multirow[t]{4}{*}{2.} & Aspek Isi/Materi & Kesinambungan materi/konten yang tersaji \\
\hline & & Kesesuaian soal dengan tujuan pembelajaran \\
\hline & & Soal yang diberikan mudah dimengerti dan tidak ambigu \\
\hline & & Ketepatan penggunaan Kaidah bahasa \\
\hline
\end{tabular}

(Modifikasi dari Suartama, 2016)

Tabel 2. Kisi-Kisi Instrument Uji Coba Ahli Desain Pembelajaran

\begin{tabular}{|c|c|c|}
\hline No & Aspek & Indikator \\
\hline 1 & Aspek Pembelajaran & 1. Kesesuaian media dengan tujuan pembelajaran \\
\hline 2 & Aspek Isi/Konten & $\begin{array}{l}\text { 1. Terdapat contoh yang relevan untuk mempermudah dalam } \\
\text { memahami materi } \\
\text { 2. Ketepatan penggunaan desain rancangan penyajian materi } \\
\text { 3. Strategi penggunaan media secara langsung dan tidak } \\
\text { langsung } \\
\text { 4. Relative advantage, ketepatan pemilihan media }\end{array}$ \\
\hline
\end{tabular}


dibandingkan dengan media lain

$3 \quad$ Aspek Afektif
1. Memberikan motivasi belajar bagi siswa

2. Media interaktif mampu meningkatkan perhatian siswa dalam belajar

(Modifikasi dari Suartama, 2016)

Tabel 3. Kisi-kisi Instrumen Ahli Media Pembelajaran

\begin{tabular}{lll}
\hline No & Aspek & \multicolumn{1}{c}{ Indikator } \\
\hline 1 & Aspek Tampilan & 1. Ketepatan teks yang digunakan \\
& 2. Kesesuaian tata letak gambar \\
& 3. Kejelasan suara \\
& 4. Kreativitas dalam pembuatan video \\
& 5. Kualitas tampilan layar \\
& 6. Ketepatan pemberian umpan balik \\
& 7. Kesesuaian desain cover dengan isi media \\
& Aspek Navigasi & 1. Navigasi mudah digunakan \\
& 2. Navigasi jelas dan tidak membingungkan siswa
\end{tabular}

(Modifikasi dari Suartama, 2016)

Tabel 4. Kisi-kisi Instrument Uji Coba Perorangan dan Kelompok Kecil

\begin{tabular}{lll}
\hline No & \multicolumn{1}{c}{ Aspek } & \multicolumn{1}{c}{ Indikator } \\
\hline 1 & Aspek Pembelajaran & 1. Kemenarikan media pembelajaran \\
& & 2. Kombinasi warna dalam media pembelajaran ini \\
& & menarik
\end{tabular}

Data pada penelitian ini diolah dengan menggunakan teknik analisis data deskriptif kuantitatif. Analisis deskriptif kualitatif digunakan untuk mengolah data kualitatif yang diperoleh melalui kusioner yang diubah menjadi nilai atau kategori dengan acuan tabel yang diadaptasi dari (Tegeh \& Jampel, 2017:223) seperti yang tersaji pada tabel 5.

Tabel 5. Konvensi Tingkat Pencapaian dengan Skala 5

\begin{tabular}{ccc}
\hline Tingkat Pencapaian (\%) & Kualifikasi & Keterangan \\
\hline $90-100$ & Sangat baik & Tidak perlu direvisi \\
$80-89$ & Baik & Sedikit direvisi \\
$65-79$ & Cukup & Direvisi secukupnya \\
$55-64$ & Kurang & Banyak hal yang direvisi \\
$1-54$ & Sangat Kurang & Diulangi membuat produk \\
\hline
\end{tabular}


Dalam penelitian ini, ditetapkan nilai kelayakan minimal "baik", sebagai hasil penilaian dari ahli isi pembelajaran, ahli desain pembelajaran, ahli media pembelajaran, uji coba perorangan dan uji coba kelompok kecil. Jika hasil penilaian akhir (keseluruhan) pada setiap aspek mendapatkan nilai minimal "baik", maka produk hasil pengembangan tersebut dianggap layak digunakan sebagai sumber belajar.

\section{HASIL DAN PEMBAHASAN}

Hasil penelitian pada pengembangan ini akan membahas mengenai proses pengembangan media pembelajaran interaktif dan validitas media pembelajaran interaktif. Proses pengembangan media pembelajaran interaktif pada penelitian ini menggunakan model pengembangan ADDIE. Model ADDIE merupakan model yang mudah diterapkan di mana proses yang digunakan bersifat sistematis dengan kerangka kerja yang jelas menghasilkan produk yang efektif, kreatif, dan efisien (Angel Learning, 2008).

Dalam pengembangan media interaktif ini melewati lima tahapan. Tahap pertama adalah tahap analisis, pada atahp ini ada empat hal yang dianalisis yaitu 1) analisis kebutuhan, 2) analisis karakteristik siswa, 3) analisis kompetensi, 4) analisis sarana dan prasarana. Tahap analisis ini dilakukan melalui wawancara dan kusioner melalui google form. Tahap yang kedua adalah tahap desain. Pada tahap ini yaitu 1) pembuatan flowchart, 2) mengembangkan storyboard, 3) pemilihan software yang akan digunakan, software yang digunakan yaitu Adobe Flash CS5, Corel Draw X4, Adobe Photoshop CS6, Microsoft Office, 4) meyusun instrumen penilaian.

Tahap ketiga yaitu tahap pengembangan. Tahap ini merupakan tahap mengembangkan rancangan yang sudah dibuat mejadi sebuah produk nyata yang nantinya akan diuji kelayakannya dilapangan. Tahap yang keempat yaitu tahap implementasi. Pada tahap implementasi kegiatan yang dilakukan yaitu 1) uji validitas produk oleh para ahli diantaranya, ahli isi pembelajaran, ahli desain pembelajaran, ahli media pembelajaran, 2) uji coba produk yang meliputi uji coba perorangan dan uji coba kelompok kecil. Tujuan dilakukan uji validasi produk dan uji coba produk adalah untuk mengetahui kemenarikan, keefektifitasan produk dan kelayakan produk yang dikembangkan sebagai sumber belajar. Tahap terakhir yaitu tahap evaluasi. Tahap evaluasi merupakan tahap untuk merevisi kembali sesuai dengan masukan, saran dan komentar yang diterima setelah uji kelayakan dilakukan kepada siswa. Hasil validitas media pembelajaran interaktif ditentukan berdasarkan hasil review dari ahli isi pembelajaran, ahli desain pembelajaran, ahli media pembelajaran, uji coba perorangan, uji coba kelompok kecil. Berikut hasil review hasil validitas media interaktif pembelajaran prakarya pada tabel 6 .

Tabel 6. Hasil Review Hasil Validitas Media Interaktif Pembelajaran Prakarya

\begin{tabular}{llll}
\hline No & \multicolumn{1}{c}{ Subjek } & \multicolumn{1}{c}{ Hasil Validitas } & \multicolumn{1}{c}{ Keterangan } \\
\hline 1 & Uji Ahli Isi Pembelajaran & $97,5 \%$ & Sangat Baik \\
2 & Uji Ahli Media Pembelajaran & $84,44 \%$ & Baik \\
3 & Uji Ahli Desain Pembelajaran & $88,57 \%$ & Baik \\
4 & Uji Coba Perorangan & $93,33 \%$ & Sangat Baik \\
5 & Uji Coba Kelompok Kecil & $94,58 \%$ & Sangat Baik \\
\hline
\end{tabular}

Berdasarkan hasil uji validitas produk media pembelajaran interaktif yang dialakukan oleh ahli isi pembelajaran Prakarya memperoleh persentase 97,5\% dengan kualifikasi sangat baik, ahli media pembelajaran memperoleh persentase $84,44 \%$ dengan kualifikasi baik, uji ahli 
desain pembelajaran memperoleh persentase $88,57 \%$ dengan kualifikasi baik, uji coba perorangan memperoleh persentase 93,33\% dengan kuaifikasi sangat baik, dan uji coba kelompok kecil memperoleh persentase $94,58 \%$ dengan kualifikasi sangat baik. Melalui hasil validitas, produk media interaktif pembelajaran mendapatkan saran, masukan, dan komentar yang selanjutkan akan djadikan sebagai acuan untuk merevisi produk demi kesempurnaan produk media pembelajaran interaktif. Hasil pengembangan media pembelajaran interaktif tersaji pada gambar 1, 2, 3, dan 4 .

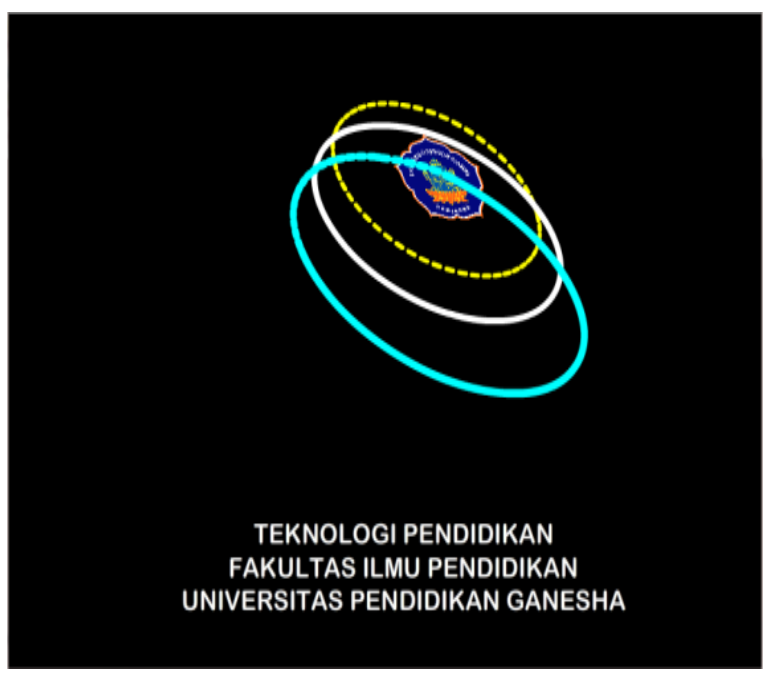

Gambar 1. Halaman Opening

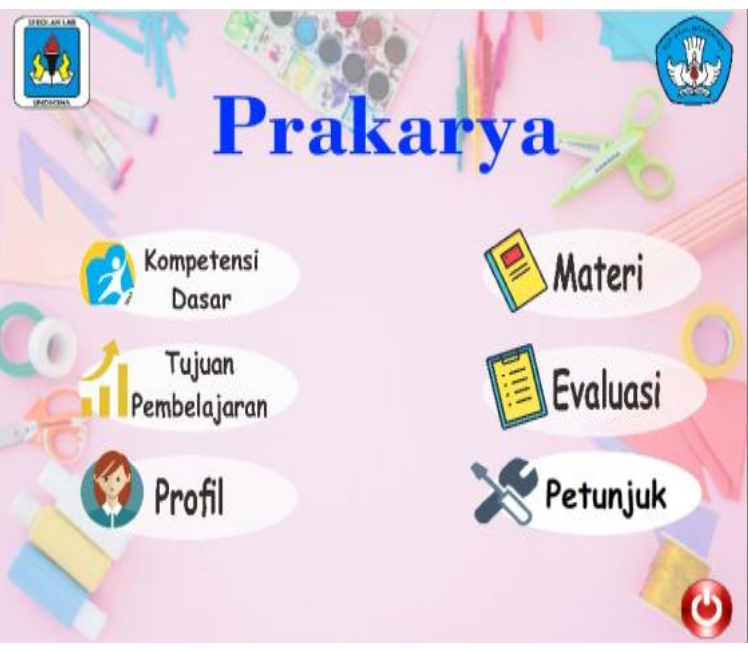

Gambar 2. Halaman Menu

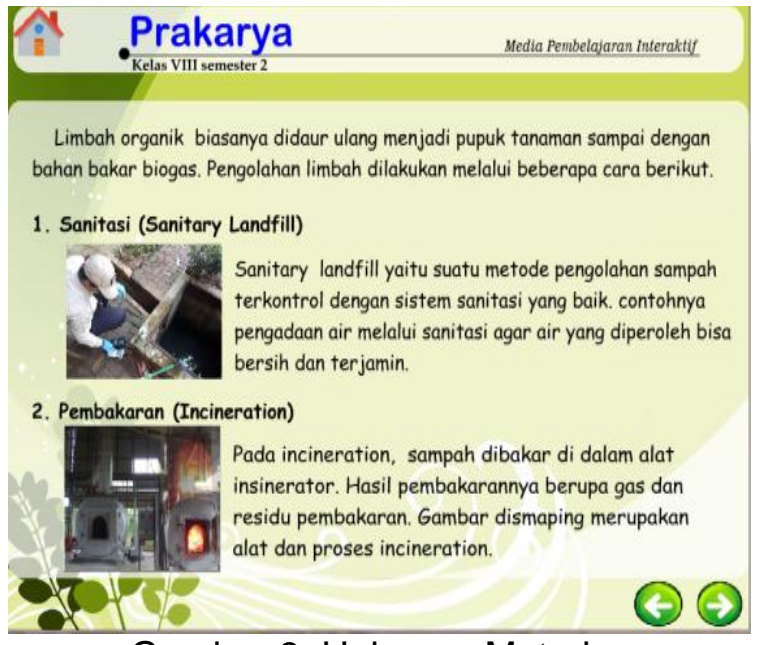

Gambar 3. Halaman Materi

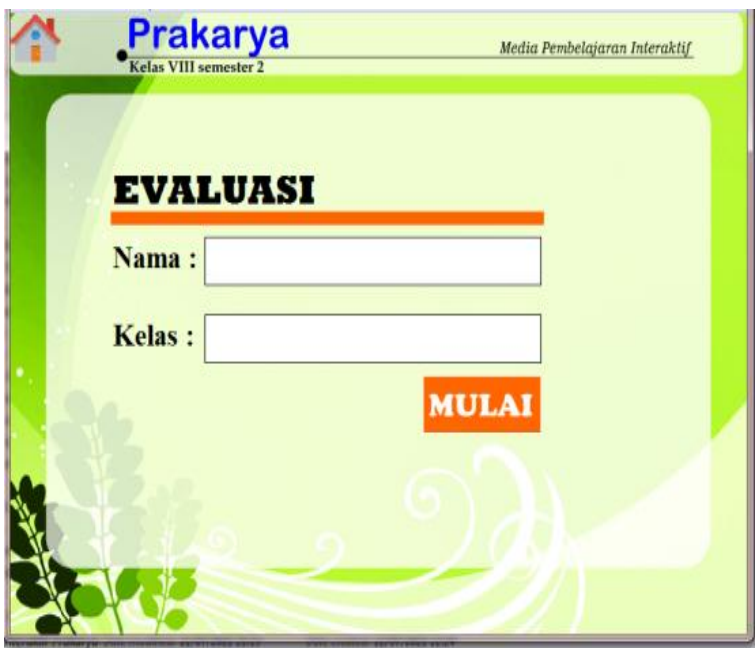

Gambar 4. Halaman Evaluasi

Berdasarkan hasil uji validitas yang sudah dilakukan, media pembelajaran interaktif yang dikembangkan memenuhi kelayakan untuk digunakan sebagai sumber belajar, baik itu dari segi ahli isi, ahli desain, ahli media dan uji coba produk yang dilakukan oleh siswa kelas VIII SMP Laboratorium Undiksha Singaraja. Hal ini juga dikarenakan proses pengembangan media pembelajaran interaktif menggunakan model pengembangan yang sistematis sehingga dapat meminalisir kesalahan dalam proses pengembangan. Pengembangan media pembelajaran interaktif ini menggunakan model ADDIE yang melewati lima tahapan pengembangan yaitu tahap analisis, tahap desain, tahap 
pengembangan, tahap implementasi, dan tahap evaluasi, sehingga hal inilah yang menyebabkan proses pengembangan media pembelajaran interaktif ini lebih efektif dan sistematis.

Berdasarkan hasil review ahli isi pembelajaran, didapatkan nilai sebesar $97,5 \%$ dengan persentase sangat baik. Berdasarkan hasil yang diperoleh dari uji ahli isi pembelajaran, media interaktif pembelajaran prakarya tepat digunakan sebagai media untuk mendukung proses pembelajaran prakarya kelas VIII. Hal ini karena materi yang dibahas dalam media sudah sesuai dengan kompetensi dasar, serta tujuan pembelajaran yang digunakan. Selain itu materi yang disampaikan secara rici dan contoh yang sangat jelas sehingga dapat membantu siswa memahami materi. Hal tersebut sejalan dengan yang diungkapkan Sukiyasa \& Sukoco (2013) bahwa materi yang disampaikan secara jelas dan lebih nyata akan dapat membantu siswa untuk lebih mengerti dan memahami materi yang dijelaskan serta dapat memberikan hasil belajar yang lebih baik. Materi pembelajaran yang disajikan dengan baik akan memudahkan siswa memahami materi (Komalasari \& Rahmat, 2019; Linda et al., 2018).

Berdasarkan hasil review ahli media pembelajaran, didapatkan nilai sebesar $84,44 \%$ dengan persentase baik. Berdasarkan hasil yang diperoleh dari uji ahli media pembelajaran, media interaktif pembelajaran prakarya ini layak digunakan sebagai media pembelajaran untuk mendukung proses pembelajaran prakarya kelas VIII. Hal ini karena produk media interaktif pembelajaran prakarya ini dapat meningkatkan motivasi dan hasil belajar siswa. Selain itu kefamiliaran produk media interaktif ini juga mudah digunakan oleh siswa maupun guru. Pemanfaatan media pembelajaran interaktif dapat meningkatkan hasil belajar siswa (Lee \& Osman, 2012; Manurung \& Panggabean, 2020).

Berdasarkan hasil review ahli media pembelajaran, didapatkan nilai sebesar
$88,57 \%$ dengan persentase baik. Berdasarkan hasil yang diperoleh dari uji ahli media pembelajaran, media interaktif pembelajaran prakarya ini layak digunakan sebagai media pembelajaran untuk mendukung proses pembelajaran prakarya kelas VIII. Hal ini karena pada desain produk media interaktif dalam pembelajaran prakarya penggunaan desain rancangan penyajian materinya sagat tepat, terdapat contoh yang relevan untuk mempermudah dalam memahami materi sehingga mampu meningkatkan hasil belajar siswa. Sejalan dengan pendapat Joyoatmodjo (Mawardi et al., 2019:49) desain pembelajaran merupakan upaya pengembangan secara sistematis komponen-komponen pembelajaran dengan menggunakan teori tertentu. Dengan demikian desain pembelajaran disusun untuk membantu proses pembelajaran siswa, dimana proses belajar tersebut memiliki tahapan segera dan tahapan jangka panjang yang akan menjamin kualitas pembelajaran. (Suartama, 2010:261) menyatakan penggunaan multimedia pembelajaran dapat menghemat waktu dalam pembelajaran, sehingga melalui multimedia interaktif ini guru dapat mengoptimalkan sisa waktu lainnya untuk kegiatan-kegiatan lain seperti pengayaan dan penguatan melalui bimbingan individu.

Berdasarkan hasil review uji coba perorangan dan uji coba perorangan dan kelompok kecil, didapatkan nilai masingmasing sebesar 93,33\% dan 94,57 dan berada pada persentase sangat baik. Hal ini karena media interaktif pembelajaran prakarya yang digunakan jelas, menarik dan dapat menarik perhatian siswa serta meningkatkan motivasi siswa. Semakin tinggi motivasi belajar siswa tentu akan berdampak positif terhadap hasil belajar siswa. Hal ini sejalan dengan pendapat Wina Sanjaya (Emda, 2017:175) mengatakan bahwa dalam proses pembelajaran, motivasi merupakan salah satu aspek dinamis yang sangat penting. Sering terjadi siswa yang kurang berprestasi 
bukan disebabkan oleh kemampuannya akan tetapi karena tidak adanya motivasi untuk belajar sehingga siswa tidak berusaha untuk mengarahkan kemampuannya. Untuk meningkatkan motivasi belajar siswa tentu memerlukan hal-hal positif yang mampu menarik perhatian siswa untuk belajar (Effendi \& Hendriyani, 2020; Ishikawa et al., 2011). Salah satunya dengan menggunakan media interaktif. Berdasarkan hasil pembahasan diatas, media pembelajaran interaktif ini dapat meningkatkan minat dan motivasi siswa dalam belajar dan terimplikasi sebagai sumber belajar yang dapat digunakan dalam proses pembelajaran untuk meningkatkan hasil belajar sisw. Hal ini didasarkan pada hasil review para ahli dan uji coba.

\section{PENUTUP}

Berdasarkan pada pemaparan diatas, dapat disimpulkan bahwa penelitian pengembangan media pembelajaran interaktif dengan model ADDIE melalui lima tahapan pengembangan yaitu 1) tahap analisis (analize), 2) tahap desain (design), 3) tahap pengembangan (development), 4) tahap implementasi (implementation), dan 5) tahap evaluasi (evaluation). Melalui tahapan-tahapan pengembangan tersebut media pembelajaran interaktif pada mata pelajaran prakarya mencapai kualifikasi sangat baik, sehingga media pembelajaran interaktif ini layak digunakan sebagai sumber belajar dalam proses pembelajaran online maupun di dalam kelas untuk menarik minat belajar siswa dan meningkatkan motivasi siswa sehingga mampu meningkatkan hasil belajar siswa.

\section{DAFTAR PUSTAKA}

Agung, A. A. G. (2017). Metodologi Penelitian Kuantitatif (Perspektif Manajemen Pendidikan). Universitas Pendidikan Ganesha.

Annisa, N., Saragih, A. H., \& Mursid, R. (2018). Pengembangan Media Pembelajaran Interaktif Pada Mata Pelajaran Bahasa Inggris. Jurnal Teknologi Informasi Dan Komunikasi
Dalam Pendidikan, 5(2). https://doi.org/10.24114/jtikp.v5i2.1259 9

Bajrami, L., \& Ismaili, M. (2016). The Role of Video Materials in EFL Classrooms. Procedia - Social and Behavioral Sciences, 232(April), 502-506. https://doi.org/10.1016/j.sbspro.2016.1 0.068

Boyd, L. (2019). Using Technology-Enabled Learning Networks to Drive Module Improvements in the UK OpenUniversity. Journal of Interactive Media in Education, 2019(1), 1-7. https://doi.org/10.5334/jime.529

Buchori, Rahmawati, S., \& Wardani, S. (2017). The Development of A Learning Media for Visualizing the Pancasila Values Based on Information and Communication Technology. Jurnal Cakrawala Pendidikan, 36(3), 502-521.

https://doi.org/10.21831/cp.v36i3.1274 8

Desma, Y. (2020). Pengaruh Penggunaan Media Interaktif dan Motivasi Terhadap Hasil Belajar Sejarah Siswa SMA Negeri 1 Gunung Talang. Jurnal Kependidikan, 4(2).

Effendi, H., \& Hendriyani, Y. (2020). The Conceptual and Hypothetical Model of Interactive Blended Problem Based Learning. JPI (Jurnal Pendidikan Indonesia), $\quad 8(2), \quad 285$. https://doi.org/10.23887/jpiundiksha.v8i2.24162

Emda, A. (2017). Kedudukan Motivasi Belajar Siswa Dalam Pembelajaran. Lantanida Journal, 5(2). https://jurnal.arraniry.ac.id/index.php/lantanida/article/ view/2838/2064

Gil-Flores, J., Rodríguez-Santero, J., \& Torres-Gordillo, J. J. (2017). Factors that explain the use of ICT in secondary-education classrooms: The role of teacher characteristics and school infrastructure. Computers in Human Behavior, 68, 441-449. 
https://doi.org/10.1016/j.chb.2016.11.0 57

Gonźalez, Guzman, Dormido, \& Berenguel. (2013). Development of Interactive Books for Control Education. IFAC Proceedings Volumes (IFACPapersOnline), 46(17). https://doi.org/https://doi.org/10.3182/2 0130828-3-UK-2039.00043

Hanif, M. (2020). The development and effectiveness of motion graphic animation videos to improve primary school students' sciences learning outcomes. International Journal of Instruction, 13(4), 247-266. https://doi.org/10.29333/iji.2020.13416 a

Hendawi, M., \& Nosair, M. R. (2020). Students' technological awareness at the College of Education, Qatar University. Cypriot Journal of Educational Sciences, 15(4), 749-765. https://doi.org/10.18844/cjes.v15i4.505 7

Indah Septiani, A. nisa N. S., Septiani, I., Rejekiningsih, T., Triyanto, \& Rusnaini. (2020). Development of interactive multimedia learning courseware to strengthen students' character. European Journal of Educational Research, 9(3), 1267-1279. https://doi.org/10.12973/eu-jer.9.3.1267

Ishikawa, J., Fujita, Y., Maeda, Y., Furuta, H., \& Ikawa, Y. (2011). GNRA/receptor interacting modules: Versatile modular units for natural and artificial RNA architectures. Methods, 54(2). https://doi.org/https://doi.org/10.1016/j. ymeth.2010.12.011

Kamelia, K. (2019). Using Video as Media of Teaching in English Language Classroom: Expressing Congratulation and Hopes. Utamax: Journal of Ultimate Research and Trends in Education, 1(1), 34-38. https://doi.org/10.31849/utamax.v1i1.2 742

Komalasari, K., \& Rahmat, R. (2019). Living Values Based Interactive Multimedia in
Civic Education Learning. International Journal of Instruction, 12(1), 113-126. https://doi.org/10.29333/iji.2019.1218a

Lee, T. T., \& Osman, K. (2012). Interactive Multimedia Module in the Learning of Electrochemistry: Effects on Students' Understanding and Motivation. Procedia - Social and Behavioral Sciences, 46. https://doi.org/10.1016/j.sbspro.2012.0 5.295

Linda, R., Herdini, Sulistya, I., \& Putra, T. P. (2018). Interactive E-Module Development through Chemistry Magazine on Kvisoft Flipbook Maker Application for Chemistry Learning in Second Semester at Second Grade Senior High School. Journal of Science Learning, 2(1), 21-25. https://doi.org/10.17509/jsl.v2i1.12933

Majid, M. S. Z. B. A., Ali, M. M. B. A., Rahim, A. A. B. A., \& Khamis, N. Y. B. (2012). The Development of Technical English Multimedia Interactive Module to Enhance Student Centered Learning (SCL). Procedia - Social and Behavioral Sciences, 67, 345-348. https://doi.org/10.1016/j.sbspro.2012.1 1.337

Manurung, \& Panggabean. (2020). Improving Students' Thinking Ability In Physics Using Interactive Multimedia Based Problem Solving. Cakrawala Pendidikan, 39(2), 460-470. https://doi.org/10.21831/cp.v39i2.2820 5

Mawardi, Wardani, N. S., Hardini, A. T. A., \& Kristin, F. (2019). Model Desain Pembelajaran Tematik Terpadu Kontekstual Untuk Meningkatkan Kebermaknaan Belajar Siswa SD. Jurnal Pendidikan Dan Kebudayaan, 9(1). https://doi.org/10.24246/j.js.2019.v9.i1. p48-61

Mustika, Prasetya, E., Adhy Sugara, \& Pratiwi, M. (2017). Pengembangan Media Pembelajaran Interaktif dengan Menggunakan Metode Multimedia 
Development Life Cycle. 2(2), 121126.

https://doi.org/10.15575/join.v2i2.139

Nonthamand, N. (2020). Guideline to develop an instructional design model using video conference in open learning. International Journal of Emerging Technologies in Learning, 15(3), 140-155. https://doi.org/10.3991/ijet.v15i03.1084 2

Nurrita, T. (2018). Pengembangan Media Pembelajaran Untuk Meningkatkan Hasil Belajar Siswa. Jurnal IImu-IImu Al-Quran, Hadist, Syari'ah, Dan Tarbiah, $3(1)$. https://doi.org/10.33511/misykat.v3i1.5 2

Oke, A., \& Fernandes, F. A. P. (2020). Innovations in Teaching and Learning: Exploring the Perceptions of the Education Sector on the 4th Industrial Revolution (4IR). Journal of Open Innovation: Technology, Market, and Complexity, 6(2), 31. https://doi.org/10.3390/joitmc6020031

Prasasti, T. I., Solin, M., \& Hadi, W. (2019). The Effectiveness of Learning Media Folklore Text of North Sumatera Based on Blended Learning by 10th Grade Students of Vocational High SchoolHarapan Mekar-1 Medan. Bir-Le Journal, $4(2)$. https://doi.org/10.33258/birle.v2i4.548

Rahmi, M. S. M., Budiman, M. A., \& Widyaningrum, A. (2019). Pengembangan Media Pembelajaran Interaktif Macromedia Flash 8 Pada Pembelajaran Tematik Tema Pengalamanku. International Journal Of Elementary Education, 3(2), 178185.

https://doi.org/10.23887/ijee.v3i2.18524

Rezeki, S., \& Ishafit, I. (2017). Pengembangan Media Pembelajaran Interaktif Untuk Sekolah Menengah Atas Kelas XI Pada Pokok Bahasan Momentum. Jurnal Pendidikan Dan Pengembangan Pendidikan Fisika,
$3(1)$.

https://doi.org/doi.org/10.21009/1.0310 4

Rokhman, F., Hum, Syaifudin, A., \& Yuliati. (2014). Character Education for Golden Generation 2045 (National Character Building for Indonesian Golden Years). Procedia - Social and Behavioral Sciences, 141. https://doi.org/10.1016/j.sbspro.2014.0 5.197

Suartama, I. K. (2010). Kualitas Pembelajaran Pada Mata Kuliah Media. Jurnal Pendidikan Dan Pengajaran, 43(3), 253-262. https://doi.org/http://dx.doi.org/10.2388 7/jppundiksha.v43i3.130

Suartama, I. K. (2016). Evaluasi dan Kriteria Kualitas Multimedia Pembelajaran. Universitas Pendidikan Ganesha.

Sukiyasa, K., \& Sukoco, S. (2013). Pengaruh Media Animasi Terhadap Hasil Belajar Dan Motivasi Belajar Siswa Materi Sistem Kelistrikan Otomotif. Jurnal Pendidikan Vokasi, 3(1). https://doi.org/10.21831/jpv.v3i1.1588

Tegeh, I. M., \& Kirna, I. M. (2010). Metodeogi Penelitian Pengembangan Pendidikan. Universitas Pendidikan Ganesha.

Tegeh, M., \& Jampel, N. (2017). Metode Penelitian Pengembangan. Universitas Penddikan Ganesha.

Teng, (Mark) Feng. (2019). The effects of video caption types and advance organizers on incidental L2 collocation learning. Computers \& Education, 142. https://doi.org/10.1016/j.compedu.2019 .103655 